\title{
The Relationships among Brand Assets, Customer Satisfaction, Brand Trust, and Brand Loyalty related to Golf Products
}

\author{
Jae-Min Lee \\ Institute of Marketing Studies, sungkyunkwan University, Seoul, Korea \\ E-mail: gregfoster@hanmail.net
}

Received: May 15, 2019. Revised: September 5, 2019. Accepted: September 16, 2019.

\begin{abstract}
Purpose - In this study, it investigates the relationship among brand asset, customer satisfaction, brand trust, and brand loyalty related to golf products.

Research design and methodology - The study was conducted with 500 customers from five indoor and outdoor golf training centers located in Seoul, South Korea. The method of tabulation was developed using a nonprobability convenience sampling and the questionnaire was administered through self-administration. The survey was conducted on-site between July 2018 and August 2018 by four trained researchers, including the researchers. Five indoor golf training centers in Seoul were randomly selected, and a total of 500 samples were collected by radio at each training site. Of the 500 questionnaires collected, 449 were utilized once incomplete questionnaires were removed from the sample.

Results - This study was as follows. First, brand asset was a significant predictor of customer satisfaction. Second, customer satisfaction was a significant predictor of brand asset. Third, customer satisfaction was a significant predictor of brand loyalty. Fourth, brand trust was a significant predictor of brand loyalty. Fifth, brand asset was a significant predictor of brand trust. Finally, brand trust was a significant predictor of brand loyalty.

Conclusions - First, the results showed that brand assets had a significant impact on customer satisfaction. Second, customer satisfaction was shown to have a significant effect on brand trust. Third, customer satisfaction had a significant effect on brand loyalty.
\end{abstract}

Keywords: Brand Trust, Brand Loyalty, Customer Satisfaction, Brand Assets

JEL Classification Code: M1, M3, M 31 


\section{Introduction}

The purpose of this study is to provide a basis for managers of golf products to develop long-term marketing strategies to respond to the needs and desires of a growing customer base as well as maintain loyal customers and maximize ongoing brand assets. The purpose of this is to verify the suitability of the model established by the theoretical basis for the above year and to verify the individual. The details revealed the relationship between brand asset factors and customer satisfaction, between customer satisfaction and brand trust, between customer satisfaction and brand loyalty, between brand trust and brand loyalty, between brand assets and brand trust, and brand assets and brand loyalty.

Since the 1960s, when the first economic plan was instituted in the country, South Korea (hereafter, Korea) has achieved rapid economic growth. These economic developments have improved the national income and living standards and achieved unprecedented material affluence. This growth has continued and impacted the quality of the country's infrastructure in general. For example, since the late 1990s, sports have flourished. Advances in science and technology have increased the efficiency and productivity of enterprise activities, and transportation and communication systems have been significantly improved. As such, people are experiencing shorter working hours and a stronger work-life balance. In addition, people have begun focusing more on their well-being than they have in the past. Therefore, the importance of leisure time has increased, leading to a growth of public interest in and desire for sports activities. Among the various leisure sports activities available, both male and female professional golf has received substantial attention. As a result, golf players' promotions at home and abroad have become opportunities to gradually change the public's perception of golf, and it is expected that it will be selected to be a regular sport at the 2016 Rio de Janeiro Olympics in Brazil and become a representative leisure sport.

The positive change is a growing trend in number yoga for golf products, which is seen as a key factor in regard to promoting economic consumption that results in the development of the golf industry. In response, (Bidmon, 2017) stated that "the market is for golf clubs, clothes, bags, gloves, and balls." The majority of this equipment (80\%) is imported. As such, intangible assets, such as brand assets, brand individuality, and brand value, as well as functional quality, such as the nature of the products, have become more important as competition among companies to satisfy consumers' needs in the golf goods market grows. In other words, building a strong brand is key to longterm revenue and customer-generated methods. As a result, the development of the mass media that broadcasts Korean athletes' matches and the increasing number of golf programs have created a positive attitude toward golf. In addition, the number of golf courses has increased in the country from 141 in 1999 to 435 in 2012, further increasing the visibility of the sport. According to Elbedweihy et al. (2016), over the age of 20, 12.1\% of the population participated in some form of golf. The number of golf courses was estimated to be about 4.01 million people compared to the population, and the brand assets were affected by the activity.

Kostyra et al. (2016) emphasized the importance of marketing strategies using brand assets, arguing that differentiation can be built through competitive advantages among companies. In other words, surviving in an increasingly competitive environment, golf equipment companies need to utilize a variety of efforts to develop their own unique brand assets, thereby increasing the level of satisfaction of their customers. In terms of consumer satisfaction, Raithel et al. (2016) reported that trust is a key component of the successful landscape, while golf equipment is a very sensitive sport that requires more sophisticated copper than other sports, so, for golfers, golf equipment goes through a complex decision-making process. In other words, increasing brand confidence is a leading marketing challenge, given the six-fold cost of maintaining one existing customer (Tsao et al., 2019). It has been reported that customer satisfaction is the most important factor directly affecting loyalty in regard to brand assets (Bidmon, 2017). Customer satisfaction refers to the difference between the perceived performance and expectations of the individual after purchase compared with the perceived performance for the intended use product. According to Dawes et al. (2015), consumers who are highly loyal to a product are highly reliable, consistently prefer the product, and feel a desire to buy it. Therefore, consumers with high brand loyalty can benefit from a variety of marketing activities, such as reduced marketing costs, increased potential customers, and increased customer satisfaction. In the golf industry and industries related to golf products, the leading research studies on brand assets include golf products and golf course brand assets.

\section{Literature Review and Hypotheses Development}

\subsection{Literature Review}


The research theory set up to achieve this research purpose has been recently studied by variables, etc. In other words, it was derived based on the relationship between the brands. Based on results presented by previous studies in this area, the following assumptions were established (see Figure 1). If the positive effects of brand trust and brand loyalty by enhancing customer satisfaction by making the brand feel favorable through the value of assets, it is an important condition for the stable management and creation of the goods company. De Villiers (2015) referred to customer satisfaction as the pleasure or disappointment that consumers feel when compared with the perceived performance of a product in relation to consumer expectations. Fastoso et al. (2018) stated that trust is the difficulty that a person depends on the parties in exchange for which the group is confident. He et al. (2016) argued that brand loyalty is divided into loyalty to an enterprise brand, as is the concept of satisfaction, and that brand loyalty is an important variable when attempting to maximize the lifetime value of a product in order to keep it with the product.

\subsubsection{Relationship between brand assets and customer satisfaction}

Kostyra et al. (2016) stated that brand assets have a significant impact on customer satisfaction; brand assets have a positive impact on customer satisfaction in a study of golf customers; brand assets have a significant influence on the customer's brand's marketing and customer's relationships; and brand recognition and brand image affect customer satisfaction, while are sub-factors of brand assets.

Pedeliento et al. (2016) stated that "brand assets have a significant effect on customer satisfaction" and "customer satisfaction has a positive effect on trust." In addition, in a study by Pedeliento, customer satisfaction was reported to have a positive effect on brand assets, while Raithel et al. (2016) stated that customer satisfaction was an important factor affecting brand assets, while preferred brand repurchasing the same brand.

\subsubsection{Relationship between brand trust and brand loyalty}

According to Kostyra et al. (2016), the possibility of maintaining a relationship with a customer for a lifetime has a significant impact on the important determinant of brand loyalty. In their study, brand trust had a positive effect on brand loyalty. Zhang et al. (2017) reported that the relationship between the brand and the brand plays a decisive role in brand loyalty, while brand trust is the driving factor for brand loyalty because trust creates a highly valuable exchange relationship.

\subsubsection{The Relationship between Brand Asset and Brand Trust}

According to He et al. (2016), brand assets have a causal effect, positive, and significant impact on brand trust.

\subsection{Hypotheses development}

Perceived quality has a direct impact on customer satisfaction. Therefore, the following hypothesis was establish ed:

H1: Brand assets will have a significant effect on customer satisfaction.

In another study, Tsao et al. (2019) suggested that customer satisfaction has a positive effect on brand loyalty, w hile suggested that the leading variables for behavioral and behavioral loyalty are customer-only. Therefore, the foll owing hypothesis was established:

H2: Customer satisfaction will have a significant effect on brand loyalty.

Dawes et al. (2015) stated that brand confidence will be greater, customer satisfaction is a precursor to loyalty, a nd the relationship between satisfaction and loyalty is proportional. Therefore, the following hypothesis was establis hed:

H3: Customer satisfaction will have a significant effect on brand trust.

The relationship between customer satisfaction and brand loyalty De Villiers (2015) reported that customer satisfaction has a significant impact on brand loyalty. Therefore, the following hypothesis was established:

H4: Brand trust will have a significant effect on brand loyalty. 
He et al. (2016) also stated that high brand assets have a favorable influence on brand trust, while brand image formation has a significant impact on consumer confidence.

H5: Brand assets will have a significant effect on brand trust.

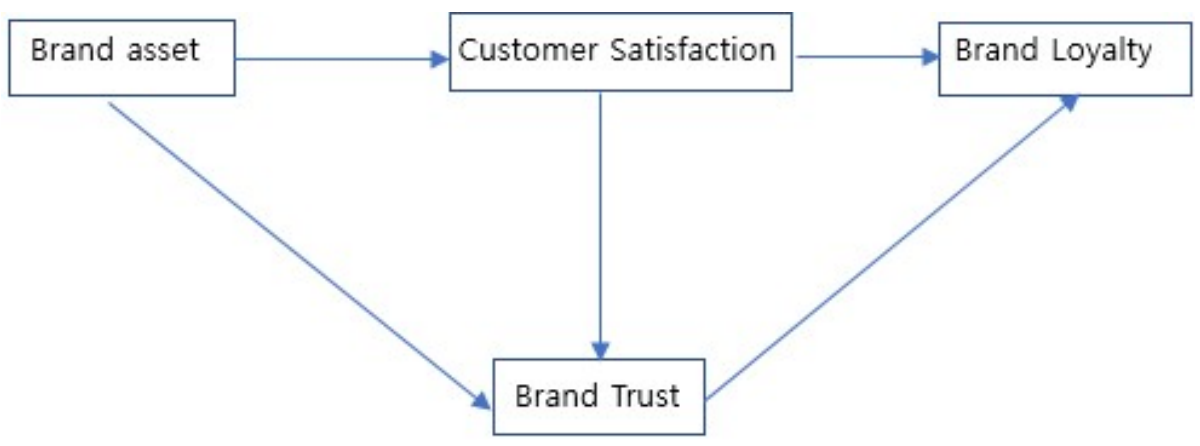

Figure 1: Research Model

\section{Methodology}

\subsection{Sample}

The sample is composed of 500 customers from five indoor and outdoor golf training centers located in Seoul, South Korea. The method of tabulation was developed using a non-probability convenience sampling and the questionnaire was administered through self-administration. The survey was conducted on-site from July 2018 to August 2018 with four trained researchers, including the researchers. Five indoor golf training centers in Seoul were randomly selected, and a total of 500 samples were collected by radio at each training site. Of the 500 questionnaires collected, 449 were utilized as the remaining had missing answers. The demographic characteristics are shown in Table 1. Two professors, one professor of Korean literature, and three PhDs in sports management were organized through a meeting by referring questionnaire used in the preceding study, which is deemed reasonable to determine each concept set for the purpose of the study, and the old volume is as follows.

\section{Results}

$<$ Table $1>$ shows that mean and standard deviation are 38.3, 73 of model 1, 52.5, 40 of model 2, 52.5, 82.3 of model 3. P value is significant of three model. $\mathrm{F}$ value is 11.57 of model 1 only.

Table 1: Descriptive Statistics

\begin{tabular}{|c|r|r|r|r|r|r|}
\hline & Coefficients & p-values & Coefficients & p-values & Coefficient & p-values \\
\hline & \multicolumn{2}{|c|}{ Model1 } & \multicolumn{2}{|c|}{ Model2 } & \multicolumn{2}{|c|}{ Model3 } \\
\hline Mean & 38.316 & 1.0000 & 52.558 & 1.0000 & 52.558 & 0.9780 \\
\hline SD & 73.080 & 0.0013 & 40.026 & 0.5671 & 82.358 & 0.1500 \\
\hline Sum of Squares & 166.5 & 0.1500 & 93.5 & 0.2500 & 260 & 0.4354 \\
\hline \multirow{2}{*}{ Mean Square } & 83.25000 & & 7.19231 & & & \\
\hline
\end{tabular}




\begin{tabular}{|c|c|c|c|}
\hline Chi-Square & 4.84 & & \\
\hline F Value & 11.57 & & \\
\hline Intercept & 0.4504155541 & -0.057399196 & -0.068328452 \\
\hline $\mathrm{x} 1$ & -0.057399196 & 0.0231208075 & -0.003105457 \\
\hline $\mathrm{x} 2$ & -0.068328452 & -0.003105457 & 0.0196940713 \\
\hline $\mathrm{N}$ & 449 & 449 & 449 \\
\hline
\end{tabular}

\section{Conclusion}

This study found that brand assets had a positive effect on customer satisfaction. Raithel et al. (2016) stated that customer satisfaction studies must be done in conjunction with a measurement of brand assets. They found that brand images affected the perception of the late guest population, which reduced negative feelings that may be caused after purchase and increased satisfaction. Tsao et al. (2019) stated that brand recognition had a static effect on customer satisfaction, while perceived quality had a direct impact on customer satisfaction. As such, customer satisfaction has a close relationship to brand assets. Therefore, it is believed that golf equipment companies should continue to evaluate brand assets through marketing activities that differentiate them from competing brands, since brand assets are built by customers' acceptance, recognition, and empathy.

The empirical analysis of Hypothesis 2 showed that customer satisfaction achieved the same results as shown in Table 9 by utilizing brand perspective (Zhang et al., 2017) and the view that trust is regarded as a prerequisite for SAS 9.4 satisfaction to verify the hypothesis based on the research model. The empirical analysis of Hypothesis 1 showed that brand assets are customer-only, with most customers having a significant impact on overall product satisfaction after product experience. Confidence in the product is based on satisfaction, and brand assets are formed when customers understand and become curious about the brand. A consumer of golf goods said that the brand will be developed in the middle stage, while Dawes et al. (2015) reported that brand assets have a higher level of confidence in the study of the structural relationship between brand assets and the intention of repurchasing them. Tsao et al. (2019) trusted his satisfaction, stated that they were formed by golf course brand assets, and stated that they had a positive effect on customer satisfaction. Given that satisfaction and trust have a positive effect on each other, De Villiers (2015) supported this study in customer satisfaction related to sports events brand assets. Therefore, the influence of golf product brands is on the market and, for the successful management of the sport, the maximization of customer satisfaction and the center brand assets are positive effects on customer satisfaction, thus gaining customers' trust. Looking at the prior study of the relationship between satisfaction and trust, the causal relationship between satisfaction and trust is discussed in different respects in previous studies. We can't increase our confidence in our products and we can' May have a direct impact on cotton-branded assets. To achieve this, it is deemed necessary to create and sustain a systematic system of services for customers who purchase golf supplies.

An empirical analysis related to Hypothesis 3 showed that customer satisfaction had a strong effect on brand loyalty. He et al. (2016) reported that customer satisfaction served as a precursor to loyalty and lead to positive oral or repurchase. According to Kostyra et al. (2016), customer satisfaction had a significant impact on loyalty; visual satisfaction had a positive impact on loyalty; customer family had a significant influence on brand loyalty; and customer satisfaction had a significant impact on loyalty, especially for service-oriented products. Pedeliento et al. (2016) stated that companies with a high level of customer satisfaction have a higher level of loyalty from their customers than companies with a low level of customer satisfaction. Zhang et al. (2017) stated that brand trust has a strong effect on brand loyalty. In other words, a company needs to increase its brand trust through honest communication with customers in order to achieve its long-term profit goal and increase sales.

An empirical analysis of Hypothesis 5 showed that brand assets have a significant effect on brand trust. Tsao et al. (2019) argued that brand trust is the most important factor between the two factors, conceptualizing brand assets as a function of the improvement of the relationship between consumers and brands, both brand image and perceived quality. Doorn et al. (2017) stated that brand assets of sporting goods have a significant impact on brand trust and "actual loyalty" in a separate study of the sub-factor of brand assets of resort hotels and behavioral loyalty. 
Customer satisfaction impacts attitude toward and loyalty to a brand. The higher the brand loyalty, the higher the customer satisfaction level. Therefore, the higher the customer's loyalty to golf equipment, the higher the customer's re-purchase intention or positive oral communication will be.

An empirical analysis of Hypothesis 4 showed that brand trust had a significant effect on brand loyalty. Dawes et al. (2015) stated that brand trust is a key factor in determining brand loyalty because it creates a highly valuable exchange relationship. In addition, De Villiers (2015) stated that brand assets have a significant impact on trust and that as consumer's brand confidence increases, so do brand assets. According to Fastoso et al. (2018) brand image had a significant impact on brand trust as brand trust increased as brand image increased. Brand image formation also had a positive impact on consumer trust (He et al., 2016). As the technology gap between companies' decreases, golf equipment manufacturers have difficulty differentiating their products based on their physical features; therefore, it is important for the companies to increase their brand confidence through brand assets.

An empirical analysis of Hypothesis 6 showed that brand assets had a strong effect on brand loyalty. According to Doorn et al. (2017), for every $5 \%$ in the number of loyal customers that a company gains, the company gains a $25 \%$ to $85 \%$ in overall return. Elbedweihy et al. (2016) stated that a customer who favored brand assets had a significant impact on brand loyalty; brand assets had a positive and strong effect on brand loyalty; brand awareness had a strong effect on brand loyalty; and the higher the brand awareness, the higher the brand loyalty.

This study was to identify and analyze the relationships among brand assets, customer satisfaction, brand trust, and brand loyalty. However, this study has several limitations that will be discussed below. First, a limit exists in regard to generalizing the results to other areas as this survey was conducted with a limited scope. In addition, the survey participants might not represent all golf players due to limitations in the number of sites chosen and that the surveys were only distributed to active players. Therefore, future research should expand the scope of the survey research and golf product buyers at national units excluding regional characteristics. Second, as limited variables were selected for this study, the model described in this study is not the optimal one.

Thus, subsequent studies should be conducted in multifaceted ways with additional variables, such as product involvement and product attitude, in relation to brand assets and brand loyalty. First, the results showed that brand assets had a strong effect on customer satisfaction. As such, it is implied that customer satisfaction has a very close relationship in determining the value of golf product brand assets. In other words, an entity needs to continue to undertake a variety of marketing activities to satisfy its customers. Second, customer satisfaction was shown to have a strong effect on brand trust. As such, to secure a large number of new customers without increasing confidence in a product, even in the short term, a breakaway rate could have a direct effect on brand assets. In other words, winning customer satisfaction and trust is brand success. Third, customer satisfaction had a significant effect on brand loyalty. The higher the brand loyalty, the higher the customer satisfaction level. In other words, products with high brand loyalty had positive effects on brand assets, which is important because they have a direct impact on customers' propensities for consumption, leading to the road to repurchase and oral communication. Fourth, brand trust had a significant effect on brand loyalty.

In order to increase sales of golf equipment, a company should actively communicate with customers to increase brand confidence, providing a platform to meet the long-term company profit goals. Fifth, it was shown that brand assets had a significant effect on brand trust. It is believed that the reason why it is important for companies to increase their confidence in brands through brand assets in recent years is because the technology gap between commodity companies is reduced and it is difficult to differentiate them from physical features for products. Sixth, brand trust had a significant effect on brand loyalty. This brand-loving product had a positive impact on brand assets, which is important because it directly affects the way in which repurchases and phrases can improve a firm's profit margins.

\section{Reference}

Bidmon, S. (2017). How does attachment style influence the brand attachment - brand trust and brand loyalty chain in adolescents. International Journal of Advertising, 36(1), 168-182.

Dawes, J., Meyer-Waarden, L., \& Driesener, C. (2015). Has brand loyalty declined? A longitudinal analysis of repeat purchase behavior in the UK and the USA. Journal of Business Research, 68(2), 427-430. 
De Villiers, R. (2015). Consumer brand enmeshment: Typography and complexity modeling of consumer brand engagement and brand loyalty enactments. Journal of Business Research, 68(9), 1956-1960.

Doorn, J., Onrust, M., Verhoef, P. C., \& Bügel, M. S. (2017). The impact of corporate social responsibility on customer attitudes and retention - the moderating role of brand success indicators. Marketing Letters, 28(4), 611-614.

Elbedweihy, A. M., Jayawardhena, C., \& Elsharnouby. (2016). Customer relationship building: The role of brand attractiveness and consumer-brand identification. Journal of Business Research, 69(8), 2905-2906.

Fastoso, F., Bartikowski, B., \& Wang, S. (2018). The "little emperor" and the luxury brand: how overt and covert narcissism affect brand loyalty and proneness to buy counterfeits. Psychology \& Marketing, 35(7), 524-530.

He, Y., Chen, Q., Tam, L., \& Lee, R. P. (2016). Managing sub-branding affect transfer: The role of consideration set size and brand loyalty. Marketing Letters, 27(1), 106-111.

Kostyra, D. S., Reiner, J., Natter, M., \& Klapper, D. (2016). Decomposing the effects of online customer reviews on brand, price, and product attributes. International Journal of Research in Marketing, 33(1), 15-21.

Pedeliento, G., Andreini, D., Bergamaschi, M., \& Sal. (2016). Brand and product attachment in an industrial context: The effects on brand loyalty. Industrial Marketing Management, 53(1), 196-203.

Raithel, S., Taylor, C. R., \& Hock, S. J. (2016). Are Super Bowl ads a super waste of money? Examining the intermediary roles of customer-based brand equity and customer equity effects. Journal of Business Research, 69(9), 3790-3792.

Tsao, Y. C., Raj, P. V. R. P., \& Yu. (2019). Product substitution in different weights and brands considering customer segmentation and panic buying behavior. Industrial Marketing Management, 77(2), 213-216.

Zhang, C., Zhuang, G., \& Yang, Z. Z. (2017). Brand loyalty versus store loyalty: Consumers' role in determining dependence structure of supplier-retailer dyads. Journal of Business-to-Business Marketing, 24(2), 142-156. 